\title{
EMMA WOOD
}

"In her prophetic fury sewed the work":

Remembering Sybil's Handkerchief and

Magical Artistries in Djanet Sears' Harlem Duet 


\section{EMMA WOOD}

\section{"In her prophetic fury sewed the work":}

Remembering Sybil's Handkerchief and

\section{Magical Artistries in Djanet Sears' Harlem Duet}

In her essay "In Search of Our Mothers' Gardens," Alice Walker defines Black-diasporic mothers and maternal ancestors as misrepresented "Artists," describing their "Art" as a "legacy" and a "gift" to their descendants that "illuminates and cherishes life." Similarly, in the preface to her 1997 theatre production Harlem Duet, Canadian playwright Djanet Sears explains that with her reimagining of William Shakespeare's Othello she is "in the process of giving birth to [her]self." Calling on this maternal-gestational link to art, Sears' play Harlem Duet retraces and revives Black maternal connections to give voice to the unheard and obscured Black women throughout Western literary history. In a pseudo-prequel to Shakespeare's work, Sears deconstructs the racist and sexist stereotyping of Black women as the obscene "witch" in Othello by re-imagining the witch as a prophet and as an artist. ${ }^{3}$ In William Shakespeare's playtext Othello, the magically cursed handkerchief was originally crafted by an unnamed sybil, a 200-year-old prophetess from Egypt who gifted the handkerchief to the mother of Othello, the play's tragic hero. The Black Moor Othello gifts the handkerchief to his white wife Desdemona as a sign of marital fidelity and, later in the play, the handkerchief's origins are misappropriated by the tragic murder of Desdemona by Othello. Sears' Harlem Duet, however, recovers the handkerchief from the historical grasp of Desdemona by redefining the "magic" of Black maternal generations. Set in 1990s Harlem, the protagonist Billie - an invocation of blues singer Billie Holiday - is mourning the end of a long-term relationship with her partner Othello when he leaves for a white woman named Mona. This play also tells the story of historical iterations of Billie in both 1860s Antebellum South and in 1928 Harlem, and the handkerchief acts as the connector between these different timelines. Despite the Shakespearean idea of the handkerchief's magic as devilish witchcraft, this paper will argue that the magic in Harlem Duet is a postcolonial symbol that rep-

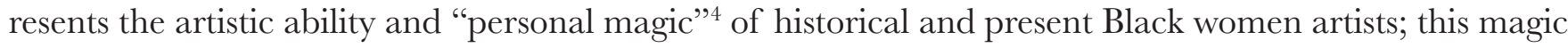
can be any type of artistry from a generational heirloom like the handkerchief to the soulful music of blues 
women like Billie Holiday. In Harlem Duet, Billie follows in the footsteps of her magical ancestor, Sybil, ${ }^{5}$ and of her prophetic chosen name, Billie, by using the handkerchief to access her lost magic and her potential as a magical being. Drawing on Alice Walker's theories on Black maternal relations and artistic ability, this paper will examine how Harlem Duet's Billie embodies past women generations and uses the handkerchief to become the prophetess who can begin to heal fractured histories through magical visions and hope for the future.

In popular discourse, the handkerchief in William Shakespeare's Othello is understood as a symbol of Desdemona's whiteness and virginity. ${ }^{6}$ According to scholar Joyce Green MacDonald in "Echoes of Harlem," the handkerchief is prominently associated with the mapping of Desdemona's "white body over the Black bodies of Othello's countrywomen," and the unnamed sybil is ostensibly forgotten and displaced by Desdemona's appropriation. For example, the sybil's story is only spoken once in the play, while Desdemona's story and tragic death overshadows the Black intergenerational experiences of the handkerchief. However, this mystification of the handkerchief's origins is a colonial erasure meant to displace the histories of African-Egyptian epistemologies and the creations of Black women artists. By situating the sybil in Egypt and displacing the handkerchief to Venice, Shakespeare draws on common misconceptions of the African continent at the time and, by defining the sybil as "a charmer" who "could almost read/ the thoughts of people," truth-seers. In this sense, Shakespeare associates the sybil's "otherness" or "ethnicity" with "innate magical powers" that depend on a stereotypical racial "frenzy," "uncontrolled passion," or power that should be feared by the West. ${ }^{9}$ Scholars Ian Smith and Joyce Green MacDonald, however, work to challenge this settler-colonial white discourse by recognizing the Black artistries and histories behind the magical handkerchief in Shakespeare's original work. For example, in his work "Othello's Black Handkerchief," Ian Smith specifically uses the handkerchief to trace the Egyptian origins of the sybil and recognizes the sybil as an artist who has access to traditional artistic methods. ${ }^{10}$ He writes, "the sibyl's sewing of the handkerchief is presented as a form of artistic creation, the 'prophetic fury' or moment of exalted inspiration precipitating the material task of sewing and dyeing." 11 In this excerpt, Smith emphasizes the sybil's intricate and time-consuming work of dyeing and sewing while also acknowledging the sybil's embodied role as the prophetess who creates with "prophetic fury." Without Shakespearean colonial discourses, this prophetic magic can also be a freeing and complex way to understand lived experiences and histories. Similarly, Djanet Sears' Harlem Duet attempts to resurrect this intricate magical tradition in the character of Billie. In her relationship and interactions with the handkerchief, Billie redefines the artistic creations of her ancestors and resituates the sybil's "feminine-authored erotic magic" 12 within the visions of new futurities and outside of the ever-present apparitions of colonial pasts.

In Sears' Harlem Duet, "Billie's very name invokes the history of Othello's prophetic sibyl” because Billie's birth name, Sybil, was given to her in the memory of her paternal grandmother. ${ }^{13}$ In the play, Billie's father, Canada, traces this history of Billie's given name of Sybil as he tells Billie, "I gave you that name. It's a good name. It was your Grandmother's name. It means prophetess. Sorceress. Seer of the future." ${ }^{14}$ Like Shakespeare's sybil, Billie is also followed and sometimes haunted by the handkerchief. Gifted to her by Othello from his maternal family, the handkerchief is described by Billie as an "heirloom" of Othello's ancestors ${ }^{15}$ and it is the most consistent symbol in the play. Constantly within a liminal space, the handkerchief itself is a testament to the "creative spark" 16 of grandmothers and mothers as it is simultaneously passed on and passed back - being defined and refined - between these maternal beings. The handkerchief is a "memory"17 and a "migratory"18 object that reminds Billie of her ancestors" historical and on-going interactions with slavery. For example, near the end of Act 1, Billie invokes the 
handkerchief as a memory object when she recounts a history of enslavement; in the nineteenth century, Othello's "great great grandmother" sobbed into the handkerchief when she was "told that her girl child, barely thirteen, would be sent "cross the state for breeding purposes." 19 Here, the magical handkerchief is the portal in which Billie is thrusted backwards into the lives of her ancestors or intimate maternal beings. Furthermore, if the handkerchief is the portal, Billie is the magical figure like a prophetess with visions of the past and future.

Amongst her various iterations throughout history, Billie occupies a liminal space in both time and place; she is quite literally torn between her present and the past. In his article "Magic Realism as Postcolonial Aesthetics in African and Africdiasporic Literatures," Ousmane Ngom defines magic realism as a literary practice for Africdiasporic literatures to infuse magic with the modern world and to infuse oppressive pasts with new futurities; to accomplish this, Ngom argues that there is a "magic character" in these literatures who play "an important role as a trigger and catalyzer of memory." ${ }^{20}$ In Harlem Duet, Billie is this "magic character" who plays both the trigger and translator for the past, and the handkerchief is the vessel for which she relays these traumatic reoccurrences and prophetic visions. This reliving of intergenerational trauma is harmful for Billie, but it also allows her to have a better understanding of her present state. For example, Magi, Billie's landlady, says that Billie is "on some archeological dig of the unconscious mind." With the handkerchief as her spade, Billie's magical ability to excavate the past, understand the present, and see the future allows her to diagnose this psychological and physiological "infestation" 22 of racism and perhaps enables her to search for the antidote or the healing cure. In the beginning, the handkerchief is presented as this magical map to freedom and healing due to its ability to survive generations of colonialism and slavery, while being a testament to times of love and joy.

The handkerchief does not merely represent past experiences of sadness and despair but also represents moments of love and marital union unmarked by surrounding racist structures. Much like the sybil in Egypt, Billie's ancestors in Harlem Duet tell stories and experiences of love and grief through the heirloom. In the 1860s on a plantation, HER, "historical strand"23 of Billie, describes the handkerchief as representative of Billie and Othello's "ancient love." ${ }^{24}$ Thus, their love can be understood as a type of magic carried on by the handkerchief. For example, later in 1990s Harlem, a love scene between Othello and Billie evokes Billie's dormant powers and potential as a seer. Billie tells Othello that their lovemaking helps her "see everything" including all of her "ancestors" before her. ${ }^{25}$ This is a moment of peace, happiness, and even health as Billie feels understood in this great circle of comforting arms of her ancestors; she says, "I know I'm supposed to be here. Everything is here."26 This is the magical healing ability of the handkerchief, and its embroidered lines and curves hold the loves, the designs, and the losses of her ancestors. Once again, Billie is channeling her past maternal ancestors by embodying this "magic character" with the ability to see and tangibly be in the past and present. ${ }^{27}$ Like the handkerchief, Billie is a magical being who acts as the vessel to hold, safekeep, and carry the horrors and hopes of the past. As the "catalyzer" of memory ${ }^{28}$ Billie is as resilient and powerful as the handkerchief itself. Throughout time, Billie is often the character who pleads with Othello to stay with her by conjuring these stories of her past maternal ancestors. In the prologue in 1928, SHE calls upon the past through the handkerchief and says to Othello, "Remember when you gave this to me? Your mother's handkerchief. There's magic in the web of it." ${ }^{29}$ In this scene, and in the entirety of the play, Billie attempts to heal her and Othello's fractured relationship by raising the handkerchief and trying to remind Othello of their eternal, impenetrable love. In each timeline from the 1860s to the 1990s, however, Othello turns away from Billie. The handkerchief is no longer powerful enough to heal this relationship and its magical legacy is once again distorted by the presence of the white woman Mona. As Mona's authority consumes this part of Billie's happiness, Billie 
must leave the handkerchief behind and return to the original forebearers and creators of the handkerchief and their eternal magic to begin to heal herself and the colonially fractured relationships of her past. With the handkerchief as a starting point, Billie embodies the converging histories of Shakespeare's sybil and post-colonial Black women artists to emerge as the prophetess with unbridled magic.

Although the handkerchief is an essential object for relating to these maternal histories, Billie also finds other artistic maternal histories of "black feminine experience" 30 outside of the handkerchief. Simply put, Billie does not need to rely on the handkerchief or Othello's love to both experience and share her magic. Billie's abilities are emphasized throughout the play when Billie would descend into sleeping dreams or day trances, and Magi once defined Billie as being in "distant realms" and "speaking in tongues." ${ }^{31}$ For instance, in the beginning of the first act, Billie has a reoccurring dream or vision where her young niece, Jenny, is being suffocated in a white room as walls press "in all around her." ${ }^{2}$ In response, Magi suggests that the dreams are "messages from other realms." ${ }_{33}$ This demonstrates Billie's potential role as prophetess beyond the actual, tangible handkerchief because these dreams or messages from other realms are perhaps the portal in which she contacts and intimately connects with her maternal ancestors - a direct line to this once obscured magic. In this specific dream, Billie draws a direct connection between her own ancestors and descendants, like her niece Jenny. In the dream, the slow suffocation of Jenny parallels the past of Billie's ancestors where their future and autonomy are already determined and stolen; but the hope in Billie's vision lies in the future and in the fact that Billie's vision of Jenny has yet to be realized. As Joyce Green MacDonald suggests, Billie realizes a "vision of a communal, borderless past and of a collective future." 34 Thus, the magic can be found in this undetermined future or in the potential new possibilities that can be imagined and conceptualized by Billie's visions. Similarly, Alice Walker defines this hope as "the respect for possibilities - and the will to grasp them." ${ }^{35}$ In a post-colonial diasporic context, the magic is in Billie's respect for the past of her maternal ancestors and the hope for the future of her niece; in other words, this magic is the future yet to be realized, the possibilities to come, and the potential of choice.

However, "the production of memory and remembrance" is "a burdensome task both in the recalling and the retelling," 36 and it slowly takes its toll on Billie as she becomes sicker and must recover in a mental health hospital. ${ }^{37}$ Once in the hospital, Billie calls out to her niece in a continuation of this generational association with the original Shakespearean sybil; she says, "it's Sybil...Auntie Sybil...The woman who lives in the cave." 38 Similar to Walker's idea of passing on the legacy of maternal feminine art, Billie also attempts to pass on her history by invoking the original sybil, the original prophetess, and trying to connect the future with the past by calling out to her niece. Once again, Billie's magical role as the "catalyzer of memory" is the only connection between the past and the future. ${ }^{39}$ In the conclusion, Billie continues this prophetic role when she reaches out to Amah, Jenny's mother, and repetitively murmurs, "I had a dream." "40 This statement dissonantly intertwines with Sears' performative use of the audio of Dr. Martin Luther King Jr.'s "I Have a Dream" speech during the Civil Rights March on Washington. Like Dr. King's and the marchers' intentions, Billie also has a dream for the future, but it is often shrouded in oppression and grief as demonstrated by the vision of Jenny being suffocated in a white room. In the end of the play, however, there is an overall aura of hope as Billie's family comforts her in the hospital and she begins to hum the lyrics to Aretha Franklin's "Spanish Harlem." 41 Similar to the lone "blooming rose" in Franklin's song, Billie stands out from the cracks in the sidewalk arising out of suppression in Harlem Duet as she represents the root or foundation of the flower as well as the blossom; she is also a testament to both the struggles and epistemologies of the past as well as the promises and capabilities of the future. Therefore, Billie's whisper of a yet unrealized dream holds so many possibilities of joy, freedom, love, and choice; this is the true magic of the handkerchief. Like the mother's garden in Alice Walker's work, the 
mother "Creator" is "involved in work her soul must have" and she is "ordering the universe in the image of her personal conception of Beauty." 43 Similarly, Billie's visions are her work, her craft - essential to her being and her survival, as she also shapes and tends to her future in her own image.

Amid her own "prophetic fury" and work, Billie harkens back to the powers of her maternal ancestors, listens to their knowledges within her subconscious, and relays her visions to her loved ones in a communal sharing of methods or remedies in generational healing. This role as prophetess, however, is no easy task and it is both physically and mentally draining for Billie, especially when the "reality" of "hundreds of years of slavery" seeps in and infests Billie's "psyche." ${ }^{44}$ In her theoretical work, Alice Walker similarly imagines a time when these prophetic voices, like Billie's or Aretha Franklin's, were stifled and oppressed; she writes, "listen to the voices of Bessie Smith, Billie Holiday, Nina Simone, Roberta Flack, and Aretha Franklin, among others, and imagine those voices muzzled for life." ${ }^{45}$ In both Sears' and Walker's work, Billie Holiday is a prominent figure for Black feminine artistic experiences and expressions. In Harlem Duet, Billie's role as artist/creator is strengthened by her association with historical blues musicians, and her chosen name of Billie "asserts identification and solidarity with a tradition of strong, independent black women blues singers." ${ }^{46}$ Like Billie's prophetic ability, Billie "Lady Day" Holiday also operates as a prophetess because she calls on past traditions of blues musical stylings of Bessie Smith or Ma Rainey while forging a new future and a new avant-garde sound in the New York cabaret blues scene. As described by Angela Y. Davis, "Billie Holiday could sing with prophetic conviction about the transformative power of love." ${ }^{\prime 47}$ In her love songs, Holiday's music described love connections and healing relationships within Black communities; for example, Holiday vocalized "love and sexuality" as a "daily experience." 48 Here, Holiday shares this humanizing and quotidian type of magic where love and different types of expressions can be found within everyday life. According to Emily J. Lordi in her work Black Resonance, "Holiday's music was a medium through which to imagine new ways of being and becoming." ${ }^{49}$ This is the dream that Billie yearns for and shares with her loved ones in the end of Harlem Duet. Unlike Holiday, Sears' Billie never vocalizes the details of this vision or dream, but the hopeful tone of the humming of Franklin's "Spanish Harlem" in the finale invokes this kind of promising interpretation. In this sense, Sears' Billie and Lady Day are intimately connected in this tradition of prophetic magic and soulful musings. Furthermore, there is a postcolonial magical component within blues music as it was formed and created from the "personal magic" 50 of predominantly Black women in diasporic America. Djanet Sears does something similar in Harlem Duet as Billie's magic transitions beyond the handkerchief and to a complex, soulful, and magical "rhapsodic blues" feminine tradition. ${ }^{51}$

This blues tradition collides with the history of the handkerchief in 1928 when Billie begs Othello to remember their love while the tragedy of their love story and history comes to the forefront:

Deadly deadly straw little strawberries it's so beautiful you kissed my fingers you pressed this cloth into my palm buried it there an antique token our ancient [...] Shhhhh OK. OK. OK. I'm ok alright don't don't don't don't my eyes on the shadow sparrow my sense in my feet my hands my feet shine the light there please scream no sing $\operatorname{sing}[\ldots]$ and if I get a notion to jump into the ocean, ain't nobody's business if I do do do do If I go to church on Sunday then shimmy down on Monday t'ain't nobody's business. ${ }^{52}$

In this melodic and repetitive monologue, Sears connects the sybil's handkerchief with Billie Holiday's famous song "Ain't no body's business if I do." ${ }^{53}$ Historically, Holiday sang this song in opposition to predominantly white popular culture's racist and misogynist judgement of her. In Harlem Duet, 1928 Billie 
is murmuring the lyrics to this song after she has slit the throat of 1928 Othello; this scene comes right after 1990s Billie and Othello are arguing over the differences between the experiences of Black men and women in America. There is a deep sorrow in Billie's rendition of this song in the scene, and it invokes different histories and stories throughout Black America. Similarly, Holiday's magic of her music both carries on a historical tradition and voices new possibilities and futurities outside of and despite of racist settler-colonial apparatuses. As Davis states in her work Blues Legacies and Black Feminism, "Holiday hardly forged this tradition - indeed, its roots lie in the early days of slavery - but she most decidedly stands as a bridge between the past and the present." ${ }^{54}$ In this sense, Holiday is also this post-colonial "magic character" 55 that occupies the in-between space of the past and present because she can "journey back through history with the goal of shedding light on the present of [her] contemporaries." ${ }^{.56}$ In the context of this blues practice, Sears' Billie is representative of Billie Holiday, and Shakespeare's sybil is the unnamed and unrecognized "musical ancestor." Sears' Billie, like the handkerchief, is the vessel or the token that can speak for the "mothers and grandmothers" who moved "to music not yet written." both Shakespeare's sybil and Billie Holiday demonstrates a complex history of pain and joy, of love and trauma, and of disruption and reclamation. Although the physical body of Billie Holiday could not live for eternity, her magic or prophetic visions live on in her musical remembrance of intimate or far-reaching ancestors and in her musical representation of the futurity of "black feminine experience." 58

From Shakespeare to Djanet Sears, the handkerchief can both destroy and heal relationships, histories, and identities. In Shakespeare, the sybil's handkerchief represents displaced and migratory pasts of Black women, misappropriation of "black" magic, and attempted destruction of Black artistic history. In Harlem Duet, however, the handkerchief represents the migration and carrying-on of Black women creative practices and artistries. As Alice Walker defines in "In Search of Our Mothers' Gardens," mothers and grandmothers have "handed on the creative spark, the seed of the flower they themselves never hoped to see." 59 From prophetess, sorceress, to songstress, Black women artists are the only reason why the handkerchief has endured and remained. This object, albeit powerful and magical, would not have attained such symbolism if not for the women who created it and continue to recreate it. The handkerchief is not merely an artistic object or piece of art; it is a lifeline through generations that continues to connect and heal both fractured pasts and bodies. In the finale of Djanet Sears' Harlem Duet, Amah says to Billie, "Something in you really wants to heal," and Billie responds with, "I wanna be free." ${ }^{60}$ In Harlem Duet's liberation of the handkerchief from colonial discourses, Sears' Billie begins to heal the wounded histories and hold hope for the future. 


\section{Endnotes}

$1 \quad$ Alice Walker, "In Search of Our Mothers' Gardens," in Maternal Theory: Essential Readings, ed. Andrea O’Reilly (Canada: Demeter Press, 2007), 94. www.jstor.org/stable/j.ctt1rrd94h.8.

2 Djanet Sears, Harlem Duet (Toronto: Scirocco, 1997), 15.

3 Walker, "In Search of Our Mothers' Gardens," 89.

4 Marissa Joseph, "Toni Morrison's Desdemona and \#BlackGirlMagic," The Sundial: ACMRS Arizona, 2020, https://medium.com/the-sundial-acmrs/toni-morrisons-blackgirlmagic-29576056eefb.

$5 \quad$ For the purposes of this paper, "Sybil” refers to Billie's grandmother and her given first name in Sears' Harlem Duet, and "sybil" refers to the original witch in Shakespeare's Othello.

6 Ian Smith, "Othello’s Black Handkerchief," Shakespeare Quarterly 64, no. 1 (2013):3-6, www.jstor.org/ stable/2477845.

7 Joyce Green MacDonald, "Echoes of Harlem: Women's Memories in Othello and Harlem Duet," in Shakespearean Adaptation, Race and Memory in the New World (Cham: Springer International Publishing AG, 2020): 112, doi: 10.1007/978-3-030-50680-3_5.

8 William Shakespeare, Othello, ed. Barbara A. Mowat and Paul Werstine (New York: Simon \& Schuster, 2009), 3.4.67-68.

9 Diane Purkiss, The Witch in History: Early Modern and Twentieth-Century Representations (London: Routledge, 2005): 264, doi: 10.4324/9780203359723.

10 Smith, "Othello's Black Handkerchief," 15.

11 Ibid, 21.

12 MacDonald, "Echoes of Harlem," 125.

13 Ibid, 121.

14 Sears, Harlem Duet, 81.

15 Ibid, 75.

16 Walker, "In Search of Our Mothers' Gardens," 93.

17 MacDonald, "Echoes of Harlem," 121.

18 Elizabeth Mazzola, "Encrypted Genealogies and Bloody Napkins: Missing Mothers in As You Like It and Othello," in Women and Mobility on Shakespeare's Stage: Migrant Mothers and Broken Homes (New York: Routledge, 2017): 81, doi: 10.4324/9781315210322.

19 Sears, Harlem Duet, 75-76.

20 Ousmane Ngom, "Magic Realism as Postcolonial Aesthetics in African and Africdiasporic Literatures," Canadian Review of Comparative Literature 47, no. 2 (2020): 203, doi: 10.1353.crc.2020.0013.

21 Sears, Harlem Duet, 30.

22 Sears, 103.

23 Margaret Kidnie, “There's magic in the web of it": Seeing Beyond Tragedy in Harlem Duet," The Journal of Commonwealth Literature 36, no. 2 (2001): 34, doi: 10.1177/002198940103600204.

24 Sears, Harlem Duet, 35.

25 Ibid, 60.

26 Ibid.

27 Ngom, "Magic Realism as Postcolonial Aesthetics in African and Africdiasporic Literatures," 197.

28 Ibid, 203.

29 Sears, Harlem Duet, 21.

30 Joseph, “Toni Morrison’s Desdemona and \#BlackGirlMagic," 2020.

31 Sears, Harlem Duet, 94.

32 Ibid, 29.

33 Ibid.

34 MacDonald, "Echoes of Harlem," 121.

35 Walker, "In Search of Our Mothers' Gardens," 94. 
36 Shelley Kulperger, "Loss of Mother/hood: Maternalising Postcolonial Cultural Memory." Hecate 33, no. 1 (2007): 237, https://link.gale.com/apps/doc/.

37 Sears, Harlem Duet, 114.

38 Ibid, 103.

39 Ousmane Ngom, "Magic Realism as Postcolonial Aesthetics in African and Africdiasporic Literatures," 203.

40 Sears, Harlem Duet, 116.

41 Ibid, 117.

42 Vicent Cucarella-Ramon, "Decolonizing Othello in search of black feminist North American identities: Djanet Sears' Harlem Duet and Toni Morrison's Desdemona," International Journal of English Studies 17, no. 1 (2017): 90, doi: 10.6018/ijes/2017/1/246541.

43 Walker, "In Search of Our Mothers' Gardens," 94.

44 Sears, Harlem Duet, 103.

45 Walker, "In Search of Our Mothers' Gardens," 89-90.

46 Jerry Wasserman, "Whose Blues? AfriCanadian Theatre and the Blues Aesthetic," Theatre Research in Canada 30, no. 1/2 (2009): 53, https://link.gale.com/apps/doc/.

47 Angela Y. Davis, Blues Legacies and Black Feminism (New York: Vintage Books, 1998), 173.

48 Davis, 173.

49 Emily J. Lordi, “Understatement: James Baldwin, Bessie Smith, and Billie Holiday," in Black Resonance: Iconic Women SingersandAfricanAmericanLiterature(NewJersey: RutgersUniversityPress, 2013): 120, doi: 10.36019/ 9780813562513.

50 Joseph, “Toni Morrison’s Desdemona and \#BlackGirlMagic,” 2020.

51 Sears, Harlem Duet, 14.

52 Ibid, 72.

53 Marlene Moser, "From Performing Wholeness to Providing Choices: Situated Knowledges in Afrika Solo and Harlem Duet." Theatre Research in Canada 29, no. 2 (2008): 253, https://link.gale.com/apps/doc/.

54 Davis, Blues Legacies and Black Feminism, 197.

55 Ngom, "Magic Realism as Postcolonial Aesthetics in African and Africdiasporic Literatures," 205.

56 Ibid.

57 Walker, "In Search of Our Mothers' Gardens," 89.

58 Joseph, “Toni Morrison’s Desdemona and \#BlackGirlMagic," 2020.

59 Walker, "In Search of Our Mothers' Gardens," 93.

60 Sears, Harlem Duet, 115. 


\section{Bibliography}

Cucarella-Ramon, Vicent. "Decolonizing Othello in Search of Black Feminist North American Identities: Djanet Sears' Harlem Duet and Toni Morrison's Desdemona." International Journal of English Studies 17, no. 1 (2017): 83-97. doi: 10.6018/ijes/2017/1/246541.

Davis, Angela Y. Blues Legacies and Black Feminism: Gertrude "Ma" Rainey, Bessie Smith, and Billie Holiday. New York: Vintage Books, 1998.

Joseph, Marissa. “Toni Morrison's Desdemona and \#BlackGirlMagic," The Sundial: ACMRS A r izona, October 13, 2020. https://medium. $\mathrm{com} /$ the-sundialacmrs/toni-morrisonsblackgirl magic-29576056eefb.

Kidnie, Margaret. "There's Magic in the Web of it": Seeing Beyond Tragedy in Harlem Duet." The Journal of Commonwealth Literature 36, no. 2 (2001): 29-44. doi: 10.1177/002198940103600204.

Kulperger, Shelley. "Loss of Mother/hood: Maternalising Postcolonial Cultural Memory." Hecate 33, no. 1 (2007): 223-242. https://link.gale.com/apps/doc/.

Lordi, Emily J. "Understatement: James Baldwin, Bessie Smith, and Billie Holiday." In Black Resonance: Iconic Women Singers and African American Literature, 99-136. New Jersey: Rutgers University Press, 2013. doi: 10.36019/9780813562513.

MacDonald, Joyce Green. "Echoes of Harlem: Women's Memories in Othello and Harlem Duet." In Shakespearean Adaptation, Race and Memory in the New World, 109-133. Cham: Springer Inter national Publishing AG, 2020. doi: 10.1007/9783-030-50680-3_5.
Mazzola, Elizabeth. "Encrypted Genealogies and Bloody Napkins: Missing Mothers in As You Like It and Othello." In Women and Mobility on Shakespeare's Stage: Migrant Mothers and Broken Homes, 77-93. New York: Routledge, 2017. doi: $10.4324 / 9781315210322$.

Moser, Marlene. "From Performing Wholeness to Providing Choices: Situated Knowledges in Afrika Solo and Harlem Duet." Theatre Research in Canada 29, no. 2 (2008): 239-257. https:// link.gale.com/apps/doc/.

Ngom, Ousmane. "Magic Realism as Postcolonial Aesthetics in African and Africdiasporic Literatures." Canadian Review of Comparative Literature 47, no. 2 (2020): 196-214. doi: 10.1353.crc.2020.0013.

Purkiss, Diane. The Witch in History: Early Modern and Twentieth-Century Representations. London: Routledge, 2005. doi: 10.4324/9780203359723.

Sears, Djanet. Harlem Duet. Toronto: Scirocco Drama, 1997.

Shakespeare, William. Othello. Edited by Barbara A. Mowat and Paul Werstine. New York: Simon \& Schuster, 2009.

Smith, Ian. "Othello's Black Handkerchief." Shakespeare Quarterly 64, no. 1 (2013): 1-25. doi:10.1353/ shq.2013.0017.

Walker, Alice. "In Search of Our Mothers' Gardens." In Maternal Theory: Essential Readings. Edited by Andrea O'Reilly, 88-95. Canada: Demeter Press, 2007. www.jstor.org/stable/j.ctt1 rrd94h.8.

Wasserman, Jerry. "Whose Blues? AfriCanadian Theatre and the Blues Aesthetic." Theatre Research in Canada 30, no. 1/2 (2009): 37-57. https://link. gale.com/apps/doc/. 